\title{
KONDISI SOSIAL PENYAIR DALAM TEKS SYAIR 1999 \\ KARYA ACHMAD MATHAR \\ (KAJIAN STRATA NORMA ROMAN INGARDEN)
}

\author{
Ikhti Nur Halimah ${ }^{1}$ \\ Afnan Arummi ${ }^{2}$ \\ ${ }^{1,2}$ Program Studi Sastra Arab Fakultas Ilmu Budaya Universitas Sebelas Maret \\ ${ }^{1}$ Email: ikhti.halimah@jatis.com
}

\begin{abstract}
This research discusses the text structure and social condition of the poet in poetry "1999" by Achmad Mathar. The purpose of this research is to outline and to describe the text structure, and the social condition of the poet in that poetry. This research uses qualitative-descriptive method by elaborating of data text that contains words, phrases, or verses. The data were analyzed using the theory of strata Roman Ingarden norm and theory of solipsism. The result shows that the text structure in the poetry "1999" by Achmad Mathar has five layers, namely the sound layer, the meaning layer, layer of things, the world layer, and metaphysical layer. The five layers of strata give rise to the impression of reading and provide in-depth meaning which can arouse the spirit of fighting to achieve independence. As for the social conditions of the poet expressed through two interrelated phenomenasof the poet. The phenomenons namely: Saddam Hussein's life story and cartoon Hanzhala by Nājī al-'Alī. Both have lofty ideals for freeing the Middle East from the influence of the West and its allies importances.
\end{abstract}

Keywords: Poetry by Achmad Mathar, Text Poetry 1999, Social Condition.

$$
\begin{aligned}
& \text { ملخص } \\
& \text { يتناول هذا البحث هيكل النص وحالةالشاعر الإجتماعية فيالشعر "999 19". يهدف هذا البحث إلى بيان هيكل } \\
& \text { النص وحالةالشاعر الإجتماعية المذكور. والمنهج المستخدم فيه هو المنهج النوعي الوصفي بإيضاح البيانات } \\
& \text { المأخوذة من الكلمة والعبارة والأبيات. وكان تحليل هذه البيانات بنظربة طبقات لرومان إنجرادين ونظرية }
\end{aligned}
$$

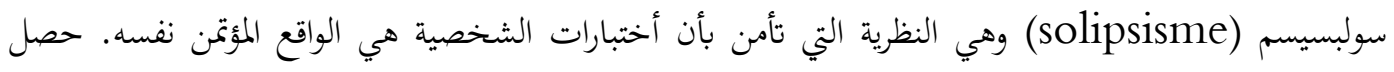

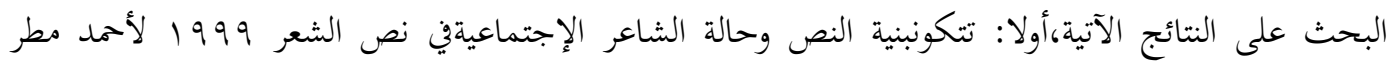

$$
\begin{aligned}
& \text { منخمس طبقات وهيالطبقات الصوتية، والطبقات المعنوية، والطبقات العناصرية، والطبقات الدنيوية والطبقات }
\end{aligned}
$$

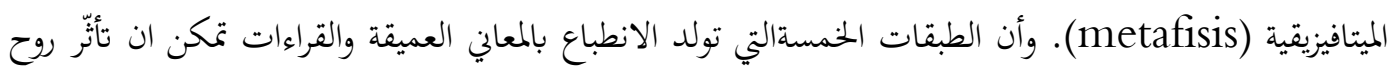

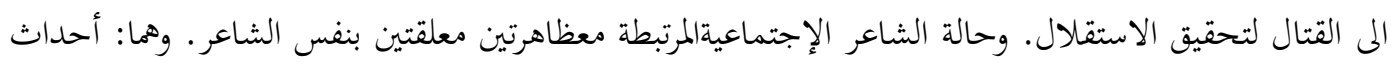

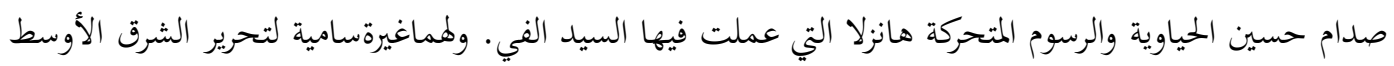

$$
\begin{aligned}
& \text { من تأثير الدول الغربية و شركاتما. } \\
& \text { الكلمات المفتاحية: شعر، أحمد مطر، } 1999 \text { 1، الحالة الاجتماعية. }
\end{aligned}
$$

\section{A. Pendahuluan}

Syair modern sangat populer diasosiasikan dengan tema politik radikal dan perubahan sosial. Pada periode ini, 
banyak penyair yang sudah meninggalkan bahasa baku sebagaimana pada puisi lama. Mereka mulai menggunakan bahasa sehari-hari dalam mengekspresikan pikirannya. Oleh karena itu, banyak syair berubah menggunakan pola syair prosa, sebuah bentuk ekspresi yang menahan sedikit mungkin karakter-karakter syair. Tidak terdapat ketajaman dalam skema berirama dalam syair Arab modern (Bustam, 2015: 124). Para penyair Arab modern juga melakukan penyimpangan dari konvensi umum sastra. Meskipun demikian, pada kenyataannya mereka tidak melepaskan diri secara total dari konvensi sastra (Muzakki, 2011: 43).

Pada syair modern, ciri yang menjadi dasar seorang penyair dalam membuat karyanya adalah ketajaman bahasa. Bahasa seorang penyair tidak muncul dari rangkaian ide, simbol, dan format yang sudah ada sebelumnya, tetapi muncul dari seorang penyair yang karena keunikan kreasinya tampak seolah-olah ia membuat suasana syair untuk pertama kalinya. Bahasa sang penyair, simbol, dan dimensi-dimensi bahasanya tidak berasal dari bahasa yang mendahuluinya, tetapi simbol dan dimensi-dimensinya muncul dan tumbuh bersama bahasanya. Para pembaca tidak dapat memahami syair dengan bersumber pada karya-karya yang mendahuluinya (mitos-mitos, Taurat, puisi Arab, atau Barat) tetapi dapat memahaminya dengan cara menyelami bahasa penyair itu sendiri (Adonis, 2009:265-266).

Selain bahasa, syair Arab modern lebih menggunakan potret realitas sosial daripada ekspresi idealisme penciptanya. Dalam hal ini, sastra realisme menjadi terlihat dominan dalam perkembangan sastra Arab modern. Dalam tataran semiotik, sastrawan Arab lebih condong ke praktik solipsisme yang berpandangan bahwa teks sebuah karya sastra hanya dapat dipahami dan dikembangkan melalui subjektivitas pembaca. Artinya, pembaca menghendaki adanya keterkaitan antara teks sastra dengan realitas sosial, tidak hanya berada pada dunia imajinasi belaka (Manshur, 2007: 22).

Terkait dengan kecenderungan dan pandangan di atas, salah satu penyair Arab modern yang berasal dari Irak, Achmad Mathar, yang kemudian disebut Mathar, mengungkapkan sebuah peristiwa yang dialaminya sejak usia kecil hingga sebelum ia wafat melalui syair bertemakan realitas politik yang berisi usaha-usaha untuk memperjuangkan hak-hak rakyat Irak dengan bahasa yang lugas. Syairsyair karangannya juga bercerita mengenai dirinya yang dibesarkan melalui pengalaman diaspora di Barat.

Mathar (أحمد مطر) dengan nama asli Achmad Mathar Abu Syachchah adalah seorang penyair muslim yang lahir pada tahun 1954. Sumber lain mengatakan bahwa ia lahir pada 1956 (Fathoni, 2007: 31) di Tanumah, sebuah desa di Basrah, Irak Selatan. Saat masih kanak-kanak, ia bersama keluarganya pindah ke seberang sungai di wilayah Al-Ashmu'i. Ia adalah anak keempat dari sepuluh bersaudara laki-laki dan perempuan. Ia menikah dan memiliki tiga putra dan seorang putri. Pada 22 Mei 2014, Mathar meninggal dunia di London (https://fr.wikipedia.org/wiki/Ahmad_Mat ar).

Mathar menyelesaikan pendidikan dasarnya dai Madrasah Al-'Adnāniya. Pada masa itu, kemiskinan yang parah dan hidup serba kekurangan terjadi dalam hidupnya. Mathar pun berkeinginan kuat untuk mengubah kehidupannya dan membebaskan dirinya dari keadaan tersebut. Ketika berusia 14 tahun tepatnya pada awal-awal tahun 1970-an, ia mulai menulis syair. Syair pertamanya selalu berkaitan dengan tema-tema cinta, romantisme, serta kesedihan (http://www.alnakedaliraqi.net/article/429 46.php).

Fathoni

mengungkapkan bahwa konflik yang terjadi antara pemerintah dan rakyat membuka hati Mathar. Kepekaan sosialnya tinggi dan semangat juangnya yang menggebu-gebu membuat dirinya tidak bisa diam melihat kenyataan itu serta bersenang-senang di tengah penderitaan orang banyak. Hal inilah yang melatarbelakangi keputusannya untuk terjun ke kancah politik. 
Perjalanan politiknya tidak berjalan mulus, sebuah peristiwa politis yang akhirnya memaksa Mathar harus mengungsi ke Kuwait untuk menyelamatkan diri. Dia pindah ke Kuwait setelah kehilangan beberapa saudaranya, pertama bernama Zaki yang meninggal karena kecelakaan mobil. Kedua, Khalid yang meregang nyawa di tiang gantungan. Dia hidup di Kuwait selama bertahun-tahun hingga dia bekerja di surat kabar Kuwait, Al-Qabas sebagai redaktur di bidang sastra dan budaya serta bekerja di sekolah dasar saat usia 20-an.

Mathar tetap menulis syairsyairnya seolah-olah dia menulis cerita harian di buku harian pribadinya. Dia mengambil jalan untuk dapat menerbitkan syair-syairnya dan Al-Qabas adalah celah di mana dia dapat mengeluarkan idenya, membuat syair tentang bunuh diri, dan mencatat tanda-tanda peristiwa yang dialami tanpa adanya rasa takut.

Pada tahun 1986, sang politisi yang juga merupakan sastrawan itu pindah ke London. Dari London kemudian dia terbang ke Tunisia. Di tempat itu, ia banyak bersentuhan dengan sejumlah peneliti Tunisia. Akan tetapi, ia kembali menetap di London selama bertahun-tahun di tempat terpencilsebagai tujuan terakhirnya di pengasingan. Meskipun banyakterdapat rumor mengenai kematiannya, kerabat Mathar telah melaporkan di Twitter bahwa dia masih hidup.

Mathar kembali bekerja di AlQabas, yang salah satu kantornya berada di London dengan Nājī al-'Alī, seorang kartunis satiris paling terkenal di Arab. Al-'Alī dikenal karena kritiknya yang terang-terangan terhadap Israel, pemerintah AS dan Arab, termasuk pemimpin Organisasi Pembebasan Palestina (PLO) Yasser Arafat. Mereka berdua dapat menemukan diri satu sama lain dalam harmoni psikologi yang jelas. Keduanya saling mengetahui peristiwa yang dibenci, mencintai apa yang mereka sukai, dan sering bersepakat untuk mengungkapkan satu masalah tanpa persetujuan sebelumnya. Hal itu didasarkan pada kejujuran, spontanitas, kepolosan, kesatuan perasaan, dan kesamaan pandangan terhadap suatu realita, dan jauh dari jebakan ideologis.

Keharmonisan psikologis

keduanya dibuktikan dengan karya-karya jurnalistik Mathar di koran dengan spanduknya yang ada di halaman depan bersama dengan karya Nājī al-'Alī yang menyajikan tulisan dengan kartun di halaman terakhir. Dilihat dari karyanya, syair Mathar memiliki ciri khas, nadanya yang tulus disertai dengan ketajaman diksi-diksinya serta kejujuran isi syairnya, yang tak jarang membuat pihak yang berwenang marah. Syairnya sangat kritis terhadap para penguasa dan rezim Arab, termasuk kritik terhadap isu kebebasan rakyat yang dibelenggu, maraknya penyiksaan, dan pihak-pihak yang melanggengkan kekuasaan dengan segala cara. Situasi umum masyarakat Arab tersebut sangat mengecawakan baginya.

Di London, 22 Juli 1987 rekan Mathar yang bernama Nājī al-'Alī dibunuh menggunakan senapan peredam di leher bagian belakang. Ia dinyatakan koma kemudian meninggal pada 27 Agustus 1987. Kejadian tersebut membuat Mathar berpikir harus membalas pihakpihak yang dengan kejam telah menewaskan rekannya melalui pena yang ia miliki, yakni melalui ungkapan syairsyairnya. Ia berpandangan bahwa syair merupakan hal penting bagi orang Arab dan merupakan bentuk seni yang bertujuan untuk memaparkan dan menguraikan realitas serta memiliki citacita hingga masa depan. Baginya, syair berfungsi menerangi jalan dan memandu perbuatan manusia.

Mathar juga memfokuskan syairnya pada kritik politik rezim Arab termasuk saat Arab Spring yang meletus pada tahun 2011. Setelah terjadi banyak pemberontakan Arab pada tahun 2011, Mathar berbicara dengan fasih tentang syair dalam konteks aksi: 'Syair bukanlah rezim Arab yang jatuh dengan kematian penguasa". Banyak kaum revolusioner di dunia Arab dan mereka yang mengendalikan rezim dapat menemukan jalan mereka sendiri dengan tanda-tanda yang dibuat oleh Mathar. Orang-orang 
memberikan julukan Mathar sebagai raja penyair.

Saat berada di London, Achmad Mathar menerbitkan sebuah buku yang dicetak atas biayanya sendiri dan diterbitkan di perpustakaan Dāru Al-Saki dan Al-Ahram. Koleksi lengkapnya meliputi tujuh buku dan termasuk beberapa dokumen syair lainnya serta beberapa syair yang tersebar yang tidak memiliki judul tertentu (http://www.alnakedaliraqi.net/article/429 46.php). Di antara karya Mathar adalah Al-A'mālul Kāmilah yang terdiri dari beberapa judul seperti Qablal Bidāyah, Al-Gharību, 'Adālah, Chikāyatu 'Abbās, Al-Jazā'u, Zamanul Kharāfi, Ramādun, Hayya 'Alal Jihād, 1999, Kāna Yā Mā Kāna, Syamūkhun, Là Mafarra.

Salah satu karyanya yang berjudul 1999 merupakan satu-satunya judul syair yang dibuat dalam bentuk angka,berbeda jika dibandingkan dengan judul-judul syair lainnya. Angka tersebut menyimpan makna dari peristiwa tertentu yang ingin disampaikan penyair secara khusus kepada para pembaca. Buku Al-A'mālul Kāmilah tersebut diterbitkan oleh Dāru alKhulüdi Linasyri Wa at-Tauzì'i pada 2013. Secara keseluruhan, di dalam buku ini terdapat 217 (dua ratus tujuh belas) judul karya. Adapun penelitian ini mengambil syair yang berjudul 1999 yang berisi 53 (lima puluh tiga) bait pada halaman 448-451.

Secara umum, syair tersebut bercerita tentang 'tiga orang jahat' yang memiliki kekuatan dan kekuasaan. Mereka menghadapi 'seseorang' yang lemah dan tidak memiliki pendukung. 'Ketiga orang jahat' dalam syair tersebut memintanya untuk menjadi budak dan tunduk terhadap perintah 'mereka'. Akan tetapi, 'seseorang' itu tidak berkehendak demikian. 'Dia' tetap berdiri tegap di depan 'mereka'. 'Ketiga orang jahat' itu tidak dapat melihat dan tidak menyadari bahwa 'seseorang' yang ada di hadapan 'mereka' adalah 'seseorang' yang agung. 'Dia' juga tetap mampu menjadi saksi akan datangnya kemenangan sampai adanya revolusi. Seiring berjalannya waktu, 'ketiga orang jahat' menyadari dan melarikan diri atas kenyataan yang terjadi, sedangkan 'seseorang' tersebut menikmati kemuliaannya dengan tetap tunduk kepada Allah SWT. 'Dia' percaya bahwa Allah SWT memberikan balasan yang khusus dan tidak terduga kepadanya karena kesabarannya serta memberikan ganjaran kepada 'orang-orang jahat' tersebut dengan mengambil kenikmatan dan memasukkan 'mereka' ke dasar api neraka (Mathar, 2013:448-451).

\section{B. Kerangka Teori dan Metodologi}

Dalam analisis struktur teks, peneliti menggunakan teori strata norma Roman Ingarden. Teori tersebut terdiri dari lima lapis, yaitu:

1. Lapis Bunyi (Sound Stratum) Bunyi dalam puisi berfungsi untuk mendapatkan keindahan, tenaga ekspresif, memperdalam ucapan, menimbulkan rasa, dan menimbulkan suasana yang khusus. Bunyi ini erat kaitannya dengan anasir-anasir musik, seperti: lagu, melodi, dan irama. Beberapa rangkaian bunyi sebagai norma dalam syair yaitu: Irama, Kakofoni (cacophony), Asonansi, Anafora dan Epifora dan Repetisi.

2. Lapis Arti (Units of Meaning) Satuan terkecil berupa fonem. Satuan fonem berupa suku kata dan kata. Berawal dari kata dapat bergabung menjadi kelompok kata, kalimat, alinea, bait, bab, dan seluruh rangkaian cerita. Lapis arti menimbulkan lapis yang ketiga yaitu lapis hal-hal yang dikemukakan (Pradopo, 2012:17).

3. Lapis Hal-Hal yang Dikemukakan Perihal yang dikemukakan dalam lapis yaitu berupa latar, pelaku, dan dunia pengarang. Dunia pengarang adalah ceritanya, yang merupakan dunia yang diciptakan oleh si pengarang. Ini merupakan gabungan dan jalinan antara objek-objek yang dikemukakan, latar, pelaku, serta struktur ceritanya (2012: 18).

4. Lapis Dunia

Lapis ini merupakan lapis 
keempat yang ada karena lapis hal-hal yang dikemukakan. Lapis ini tidak perlu untuk dinyatakan, tetapi sudah implisit (2012: 18).

5. Lapis Metafisis

Lapis terakhirberupa pengungkapan ketragisan hidup manusia dan peristiwa-peristiwa yang menimbulkan para pembaca dapat berkontemplasi atau melakukan renungan (2012: 19).

Dari kelima lapis di atas, dijabarkan pula ungkapan dalam bait-bait yang dapat dikaitkan ke dalam ilmu pengetahuan sosial yang relevan dengan syair. Sehingga struktur dan pemaknaan syair lebih dipahami oleh para pembaca.

Teori selanjutnya yaitu teori solipsisme (solipsism). Teori ini berupa pandangan yang menyebutkan bahwa pengalaman pribadi seseorang adalah satu-satunya realitas yang dapat dipercaya. Dengan kata lain, seseorang tidak memiliki landasan untuk percaya akan apa saja yang lain daripada dirinya sendiri.

Solipsisme berasal dari bahasa Latin 'solus' yang berarti 'sendirian' dan 'ipse' yang berarti 'diri'. Akar dari paham ini dipandang berasal dari pemikiran Gorgias, seorang Sofis (483-375 SM) dan disempurnakan oleh Descartes. Di zaman modern solipsism disempurnakan oleh George Barkeley sebagai teori materialisme-imaterialisme yang berkaitan dengan kepercayaan terhadap Tuhan. Saat ini, isitlah ini menjadi bahan kajian bidang psikologi dan psikiatri (Bagus, 2000: 1028-1029). Terdapat dua macam solipsisme:

1. Solipsisme epistemologi yang menyebutkan bahwa kesadaran manusia tidak dapat mengerti apa pun selain daripada dirinya sendiri.

2. Solipsisme metafisik yang menerangkan bahwa tidak ada realitas lain selain daripada dirinya sendiri. Segala sesuatu yang hadir yaitu ciptaan kesadaran seseorang pada saat dia sadar akan hal-hal tersebut. Dengan demikian, hal-hal lainnya tidak memiliki eksistensi.

Dalam pemaknaan karya sastra, logika objektif tidak selalu dapat ditemukan ketika peneliti memaknai karya sastra dan maksud pengarang. Peneliti boleh saja menafsirkan karya sastra menurut kriteria yang telah dibangun. Makna itu ada karena 'diadakan', bukan dibentuk oleh pengarang. Karya sastra yang sudah dipublikasikan ke publik merupakan hak dari para pembaca untuk memaknainya (Endraswara, 2012:126).

Adapun metode yang digunakan dalam penelitian ini adalah kualitatif deskriptif. Metode ini dianggap sebagai multimetode sebab penelitian pada gilirannya melibatkan sejumlah besar gejala sosial yang relevan. Dalam penjelasan makna teks syair 1999 karya Mathar digunakan pembagian jeda syair yang disebut jeda syair jarak estetik I, II, dan III. Adapun pengertian dari jarak estetik adalah keterpisahan dari karya seni (Zaidan, 1994: 92-93).

\section{Pembahasan}

Kondisi sosial penyair berkaitan erat dengan karya sastra yang diciptakan. Oleh karena itu diperlukan pemahaman terhadap struktur yang membangun dalam teks syair 1999 karya Mathar agar para penikmat sastra dapat memaknai syair ini dengan tepat. Struktur yang dimaksud dapat dikaji menggunakan paham strukturalisme yang terdapat dalam teori strata norma Roman Ingarden.

Dalam analisis teks syair ini, dilakukan deskripsi lapis-lapis strata norma yang secara substansial digunakan untuk memaknai kondisi sosial penyair, yaitu lapis arti (units of meaning) dan lapis hal-hal yang dikemukakan.

\section{Analisis Struktur Teks Syair 1999}

\section{a. Jeda Syair Jarak Estetik I}

1) Lapis Arti (Units of Meaning) Lapis arti yang ditemukan pada bait pertama yaitu mengenai keberadaan 'tiga orang jahat' maskulin [أَثْرَاِِ dapat dimaknai sebagai kiasan (transferred meaning, figurative meaning) yaitu pemakaian kata dengan makna yang tidak sebenarnya (Hasanuddin, 2009: 745). Selanjutnya, bait kedua 


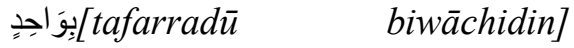

memiliki arti 'menghadapi satu orang'. Dalam syair ini, maksud dari 'dia' yakni pelaku yang hanya berjumlah satu. Keadaan pelaku tersebut dilanjutkan pada bait ketiga

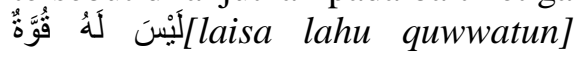
'yang tidak memiliki kekuatan' dan

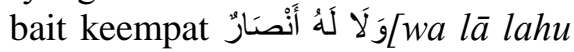
anshārun] 'dan yang tidak memiliki pendukung'. Penyair menegaskan pernyataan pelaku itu tidak memiliki pendukung untuk menghadapi 'ketiga orang'. Pada bait kelima ditemukan tanda kurung

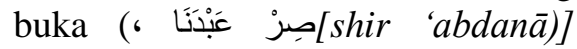
'mereka' berkata, (jadilah budak kami,' dan kurung tutup di bait keenam (... أَوْ إنَّنَاِ $[a u$ innanā...)] 'atau niscaya kami akan...)'. Kata صِ kata صَارَshāral 'menjadi' sebagai kata perintah. Kata عَدَّنَ /'abdanāl berarti 'budak kami' yang berasal dari kata /عَبُ/'abdun/ 'budak' lalu diberi imbuhan dhamir $\mathrm{i} / n \bar{a} /$. Budak merupakan orang yang dapat dipermainkan atau ditipu (KBBI, 2016: 214). Hal yang demikian merupakan kehendak 'ketiga orang jahat'. Kemudian 'mereka' juga memberikan ancaman di bait keenam yang berisi apabila 'seseorang' itu tidak mau menjadi budak, 'mereka' akan berbuat sesuatu yang sangat merugikan bagi لَكِنْهُ مَا [صَار [lakinnahū mā shara] memiliki arti 'tapi dia tidak mau (menjadi) tunduk'. Tunduk yakni menurut dan menyerah. Akan tetapi pernyataan itu dilanjutkan dengan sikapnya yang juga tidak takut terhadap ancaman yang menimpanya. Hal demikian ditunjukkan pada bait

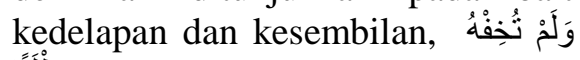
'silwa lam tukhifhu muthlaqān] 'sama sekali tidak membuatnya takut' dan عَوَاقِبُ الْإِنَْار ['awāqibulindzāri] 'konsekuensi dari peringatan itu'. Penyair menekankan kembali bahwa perbuatan buruk apapun yang dilakukan oleh 'ketiga orang jahat' tidak akan berdampak apapun baginya. Kondisi 'seseorang' digambarkan lagi pada bait ke-10 sampai dengan ke-12, yaitu وَظَلََّرَغْنْ ضَwa zhalla raghmu dha'fihi] 'meskipun lemah, dia tetap', [أَمَاَْهُمْ [muntashiban amāmahum] 'berdiri di depan mereka', الْمِنْمَارُ [kaannahul mismāru] 'seperti paku'. Kemudian kata ضَعْفِ berasal dari kata /ضَعْفِ dha'fun/ yang berarti lemah. Lemah diartikan tidak kuat, tidak bertenaga (KBBI, 2016: 807).

2) Lapis Hal-Hal yang Dikemukakan Perihal yang dikemukakan dalam lapis ini berupa latar, pelaku, dan dunia pengarang yang dapat bersifat abstrak dan konkret. Dalam praktiknya, pelaku yang dikemukakan adalah 'tiga orang jahat', 'seseorang' yang dianggap lemah. Kemudian objek yang menjadi sorotan yaitu 'kekuatan' dari kedua belah pihak, sedangkan suasana yang digambarkan yaitu mencekam ketakutan apabila peristiwa tersebut dirasakan oleh 'orang biasa'.

b. Jeda Syair Jarak Estetik II

1) Lapis Arti (Units of Meaning) Lapis arti pada jeda syair jarak estetik I diakhiri dengan keadaan 'seseorang' yang dianggap lemah padahal tidak demikian. Kemudian, pada jeda syair jarak estetik II diawali dengan karakteristik 'ketiga orang jahat'. Bait itu berawal dari bait ke-13 sampai dengan ke-18. Sebagaimana bait ke-13, رُوْسَسُهْْ هَاَِيَلَةُ 'mereka' sangat besar', bait ke-14

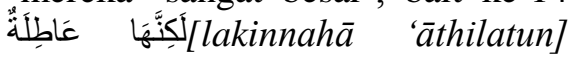
'namun tidak berguna', dan ke-15

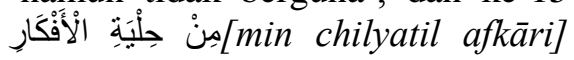

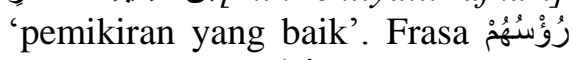
berasal dari kata رَوَّسُ yang memiliki arti 'kepala'. Kemudian ditambahkan sُ sebagai kata ganti. Dalam syair ini, kepala berarti otak (pikiran, akal, budi) (KBBI, 2016: 671), kata هَانَيَّة berarti yang sangat besar yang dapat dimaknai bahwa 
isi kepala dan pemimpin 'mereka' memang yang paling diagungkan.

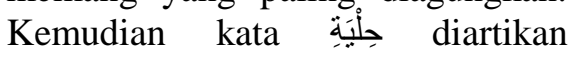
sebagai perhiasan. Seharusnya pemikiran yang merupakan anugerah dari Allah SWT dapat berfungsi sebagai perhiasan. Sebaikbaiknya manusia adalah yang berilmu dan pemikiran yang 'mereka' miliki tidak mengarah kepada keburukan. Dilanjutkan bait

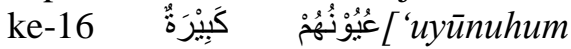
kabiratun] 'mata 'mereka' besar' berasal dari kata )عُعُونُو'uyūnun/ (mata). Mata diartikan sebagai indra untuk melihat sesuatu yang mulia. Akan tetapi, bait ke-17 menyatakan

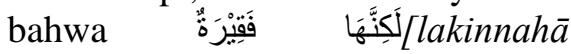
faqìratun] 'tetapi tidak memiliki'

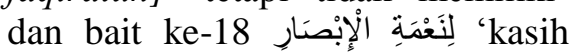
sayang'. 'Mereka' tidak memiliki perasaan kasih sayang yang mampu merasakan sesuatu yang tidak tampak melalui kehalusan jiwa dan ketajaman penglihatan. Pada bait

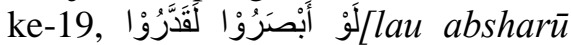
laqaddarū] jika 'mereka' bisa melihat... niscaya 'mereka' akan bisa menghitung. Lalu bait selanjutnya berbunyi كُمْ هُوَ مِنْهُمْ ! أَكَبَرُ [kam huwa minhum akbaru!] Betapa dia jauh lebih besar daripada 'mereka'. كَ memiliki arti 'berapa, berapa banyak'. Dengan adanya tanda seru (!) yang terdapat di akhir bait, كَ dapat diartikan sebagai 'betapa' 'seseorang' lebih besar seperti dalam frasa أَكَبَر 'lebih besar' daripada 'mereka'. Frasa 'أَكَبرَ' merupakan Ismu at-Tafdhīl, yaitu ism yang dibentuk untuk menyatakan perbandingan antara satu benda atau keadaan dengan keadaan yang lain (Pamungkas, 2014:111). Lebih besar dalam konteks ini yakni lebih hebat dan

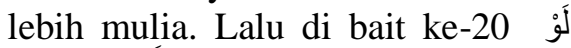

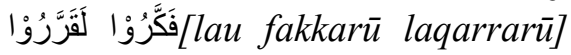
'jika 'mereka' berpikir 'mereka' pasti bisa memutuskan'. Penyair mengungkapkan bahwa 'mereka' tidak berpikir terlebih dahulu sebelum bertindak. Jika 'mereka' menggunakan pikiran 'mereka' secara jernih, maka akan diketahui bahwa 'seseorang' itu tidak akan pernah mengakui atas pernyataan 'mereka'. Dia bukanlah 'seseorang' yang biasa dan tidak dapat hancur karena ancaman. Hancur yang diartikan remuk di sini mempunyai makna kacau balau. Walaupun 'dia' dianggap lemah, 'dia' berkeyakinan bahwa dengan tekadnya dia mampu menyaksikan hari revolusi.

2) Lapis Hal-Hal yang Dikemukakan Hal-hal yang dikemukakan penyair di antaranya berupa kedangkalan pemikiran 'ketiga orang jahat'. 'Mereka' tidak mengetahui siapa sebenarnya 'seseorang' yang sedang dihadapi karena 'mereka' hanya berpikir jika yang dihadapannya adalah 'seseorang' yang tidak berdaya sehingga mudah untuk ditaklukkan.

c. Jeda Syair Jarak Estetik III

1) Lapis Arti (Units of Meaning)

Setelah jeda syair jarak estetik II diakhiri dengan keyakinan penyair terhadap kondisi yang akan berubah di masa yang akan datang, bait dimulai dengan baris ke-31. Di bait tersebut terdapat pengulangan syair sebagaimana keberadaan 'tiga orang

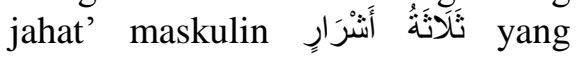
diungkapkan pada permulaan syair. 'Mereka' termasuk ke dalam referensi persona ketiga jamak. Kata 'ثَلَثَةُ 'tiga' berarti yang terbesar (terkuat, terunggul) sesuai dengan kenyataan yang ada (KBBI, 2016: 1461). Orang dapat diartikan negeri lain (KBBI, 2016: 986) dan jahat dimaknai sebagai perbuatan buruk. Maka, 'tiga orang jahat' diartikan sebagai negeri yang bertindak buruk'. Makna yang didapatkan merupakan makna kiasan (figurative meaning) yaitu pemakaian kata dengan makna yang tidak sebenarnya (Hasanuddin, 2009: 745). Bait diteruskan dengan keadaan 'ketiga orang jahat' yang berlainan dengan pernyataan di awal pembukaan syair. Di bait ke-32, فِيْ 
[حالَة إِنْتنْنَاِ 'dalam keadaan (ingin) melarikan diri'. Dapat dikatakan bahwa 'mereka' bersiap-siap kabur setelah melihat kenyataan yang sebenarnya. Lalu pada bait ke-33 تَرَدَدُوْا

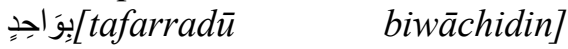
'menghadapi satu orang' berarti yang 'mereka' hadapi masih kepada 'seseorang' yang ada di bait-bait syair jeda syair jarak estetik pertama. Pada bait ke-35 تَكْرُنُ فِيْ

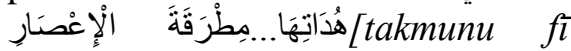
hudātihā... mithraqatal-i'shāri] 'menyimpan palu badai dalam kesunyian' penjabarannya yaitu, palu merupakan alat untuk memukul paku (KBBI, 2016: 1006). Lalu badai adalah angin kencang yang menyertai cuaca buruk (yang datang tiba-tiba). Dilanjutkan dengan kesunyian yaitu perihal sunyi dan keheningan. Palu yang diartikan sebagai 'tiga orang jahat' dengan kekuatannya tiba-tiba datang ke suatu tempat dengan cepat meninggalkan 'seseorang' hingga suasana menjadi hening seketika. Dilanjutkan pada bait ke-36 لَمْ تَبَقَ إِلَّ [lam tabaqa illà sanatan] 'hanya satu tahun tersisa' merupakan pernyataan jelas bahwa setelah kepergian 'tiga orang jahat', waktu yang difokuskan hanya pada satu tahun. Kemudian perihal yang dilakukan 'seseorang' itu ada pada bait ke-37 كَا هِيَ إِلاً سِنَّة... sinatan] 'tiada lagi selain rebah'. Dia terbaring sesaat kemudian dilanjutkan pada bait ke-38

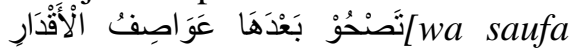
tashchī ba'dahā 'awāshiful aqdāri] 'dan setelah itu badai nasib akan bangkit'. 'Dia' dengan seketika juga, bagaikan secepat badai dapat berdiri kokoh untuk bangkit dan mengubah semua hal yang terjadi di masa lampau. Pernyataan itu ada pada bait ke-39 لَّقَقَلَّبَ الْأَدْوَارَالأlituqallibal adwāra] 'untuk mengubah peran!'. Penyair menyampaikan dengan tegas dan kuat ditandai dengan tanda baca seru (!). Suasana dalam syair sedikit meredam saat pernyataan di bait ke-

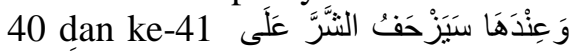
أَعْقَبِهِ syarra 'alā a'qābihi] 'dan ketika itu kejahatan akan mengikuti jejaknya',

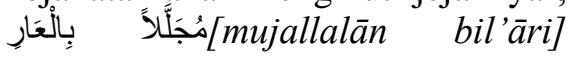
'dengan diliputi kehinaan'. Kejahatan dan dampak yang ditimbulkan akan mengikuti jejak 'ketiga orang' tersebut. Bait ke-42 [wal wāchidul maqhūru yabqa qāiman liwachdihi] 'sementara satu orang yang tertindas tadi berdiri sendirian'. Arti dari tertindas adalah teraniaya, seperti halnya yang terjadi pada 'seseorang' yang dianggap lemah. 'Dia' mendapat ancaman saat 'dia' tidak memiliki kekuatan bahkan pendukung. Akan tetapi, seiring dengan berjalannya waktu 'dia' dapat bangkit dan berdiri tanda munculnya kekuatan dari dirinya yang sebenarnya. Bait ke-43 berbunyi مُنَتَنيًاً

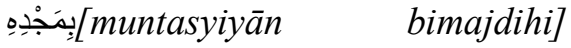
'menikmati kemuliaannya'. Maksudnya, 'seseorang' yang dimaksud dapat dengan kuat berdiri sambil merasakan kehormatan yang dia dapat dari peristiwa saat berhadapan kepada 'ketiga orang jahat'. Walaupun demikian, sikap yang ditunjukkan olehnya masih rendah hati seperti dalam bait ke-44,

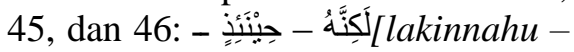
سَوْف ' chinaidzin] 'tetapi kemudian'

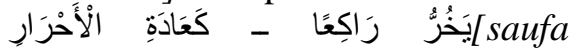
yakhurru rāki' $\bar{a} n$ - ka'ādatil achrāri -] 'dia akan berlutut seperti kebiasaan orang-orang merdeka'

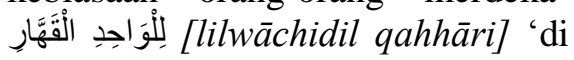
hadapan Allah yang Maha Tunggal dan Maha Perkasa'. Makna berlutut ialah bertekuk lutut di hadapan Allah s.w.tseperti halnya yang dilakukan oleh orang-orang bebas (dari perhambaan, penjajahan) (KBBI, 2016: 904). Pernyataan إذذّ جَاءَهُ diteruskan dengan bait ke-47 بنَصْنِ:[idz jāahu binashrihi] 'karena Allah datang kepadanya dengan 
pertolongan-Nya'. Allah s.w.t datang kepada hambanya yang membutuhkan bantuan. Selain memberikan bantuan, Allah s.w.t dalam bait ke-48 dinyatakan bahwa

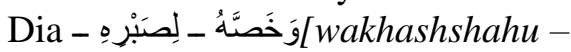
lishabrihi -] 'memberikan balasan yang besar khusus baginya karena kesabarannya'. Setelah mengetahui balasan nikmat akan kebaikan, dalam syair diterangkan perihal orang yang berbuat keburukan. Seperti halnya pada 'ketiga orang jahat' yang menghadapi 'seseorang'. Di bait ke-49 dan ke-

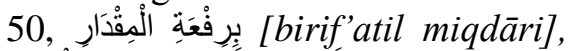

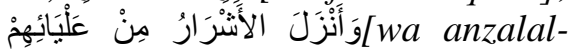
asyrāru min 'alyāihim] 'dan Allah s.w.t menurunkan orang-orang jahat dari tempat 'mereka' yang tinggi'. Maksud dari bait itu dilanjutkan pada bait ke-51 sampai ke-53 وَطَهُُْْ Lفِيْ قَعْرِ قَعْرِ النَّارِ qa'ri qa'rin nāri] 'dan melemparkan 'mereka' ke dasar api

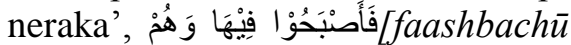
fîha wa hum] 'mereka pun masuk

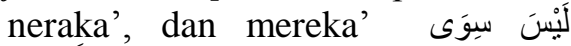
أصنفاِارِ [laisa siwā ashfārin] 'tiada lain hanyalah benda tak berguna'. Allah s.w.tmelemparkan 'ketiga orang jahat' ke neraka yang paling bawah. Maka masuklah 'mereka' ke dalamnya atas kehendak Allah s.w.t. 'mereka' juga bukanlah benda atau manusia yang berguna.

2) Lapis Hal-Hal yang Dikemukakan Pelaku yang dikemukakan merupakan pelaku yang menjadi ide pembahasan, yakni 'tiga orang jahat' dan 'seseorang'. Selain itu, terdapat latar waktu yang ditunjukkan pada bait ke-34 يَغْيْبَ فِيْيْ

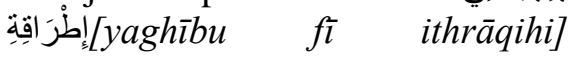
'menghilang dalam sekejap mata'. Peristiwa hilangnya 'ketiga orang jahat' dirasakan dengan cepat. Di

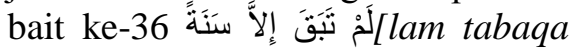
illā sanatan] 'hanya satu tahun tersisa'. Maksud dari bait tersebut adalah sisa waktu yang memungkinkan 'dia' untuk merubah keadaan yang terjadi saat itu.
Kوسَوْتَ تَصْحُوْ

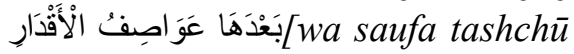
ba'dahā 'awāshiful aqdāri] 'dan setelah itu badai nasib akan bangkit'.

\section{Analisis Kondisi Sosial Penyair dalam Teks Syair 1999}

Penelitian ini menemukan dua fenomena pendukung yang dinyatakan secara implisit atas terciptanya teks syair 1999 yang terkait dengan kondisi sosial penyair, yaitu fenomena yang berkenaan dengan Saddam Hussein dan fenomena tentang perjalanan hidup Hanzhala, kartun yang merepresentasikan seorang Nājī al'Alī. Kedua fenomena tersebut, menurut peneliti merupakan hal yang melatarbelakangi Mathar dalam penciptaan karyanya.

a. Fenomena Saddam Hussein

Fenomena pertama yakni mengenai Saddam Hussein yang merupakan Presiden Irak Masa jabatan 16 Juli 1979 sampai 9 April 2003. Dia adalah seorang yang pernah memiliki hubungan baik dengan dunia Barat lalu menjadi musuh utama Barat pula. Akhir hayatnya yang berakhir di tiang gantungan tidak menandakan berakhirnya cita-cita untuk kemerdekaan total di Timur Tengah. Perjuangannya masih dilanjutkan oleh orang-orang yang memiliki tujuan kemerdekaan untuk Timur Tengah.

Menilik sejarah, sejak tahun 1956 masyarakat Irak memiliki sifat nasionalisme akibat penaklukan bangsa Jerman. Maka Saddam ingin mengembalikan jiwa nasionalisme dan semangat kebangsaan rakyatnya. Saat roda pemerintahannya berlangsung, tepat pada 4 September 1980 Irak menyatakan perang dengan Iran. Irak menyerang cadangan minyak selama delapan tahun. Saddam dibantu oleh Amerika dan Barat dalam hal persenjataan dan berbagai macam fasilitas perang karena pada saat itu mereka membenci Khomeni, Pemimpin Besar Iran. Dua tahun setelah perang Irak dengan Iran, Irak menginvasi Kuwait pada 2 Agustus 1990. Menurut Saddam, Kuwait dan Uni Emirat Arab 
mengadakan perjanjian dengan Amerika untuk menurunkan harga minyak di pasaran dunia. Kuwait dan Uni Emirat Arab terkenal sering melanggar kesepakatan kuota produksi minyak yang sebenarnya telah ditetapkan OPEC. Akibatnya overproduksi menyebabkan harga minyak jatuh.

Invasi Irak ke Kuwait membuat Amerika dan Barat memusuhi Saddam. Pada hari ketiga Saddam menduduki Kuwait, Presiden Amerika George Bush mengirim pasukannya untuk menyerang pasukan Saddam hingga hanya mampu bertahan lima bulan di Kuwait. Pada Januari 1991, Irak harus meninggalkan Kuwait. Irak mendapatkan sanksi embargo minyak. PBB mengeluarkan resolusi 1248 yang menetapkan agar Irak berhenti membangun persenjataan. Sejak itulah Saddam terisolasi dari dunia internasional tetapi dia masih tetap populer di negaranya. Terbukti pada tahun1995, dalam referendum yang diselenggarakan, hampir 99\% rakyat Irak mendukungnya untuk memimpin Irak.

Amerika Serikat terus berusaha untuk menjustifikasi Saddam agar dia dapat disingkirkan. Menurut Amerika, Saddam terlibat jaringan teroris Osama bin Laden, tetapi kebenarannya tidak pernah dibuktikan oleh Amerika. Setelah Perang Teluk Pertama berakhir pada tahun 1991, senjata pemusnah massal milik Irak telah dimusnahkan oleh PBB selama periode peluncutan senjata yaitu tahun 1991-1998. Lima persen sisanya, menurut Amerika senjata pemusnah massal itu disembunyikan oleh Saddam, akan tetapi sampai saat ini pun tidak dapat dibuktikan kebenarannya karena hal itu merupakan kebohongan Amerika Serikat untuk menyingkirkan Saddam.

Pada tanggal 20 Maret 2003, Amerika Serikat dan sekutunya meluncurkan serangan ke Baghdad. Dalam hal ini, Saddam merasa mendapatkan tekanan yang luar biasa. Jika sebelumnya, dia selalu bersikap tenang dan selalu menenangkan rakyatnya agar tidak mudah tersulut ego dan tetap menanamkan jiwa nasionalisme demi bangsa Irak dan Palestina. Pada bulan Mei
2003, Bush menyatakan perang telah berakhir dan Saddam adalah buronan yang harus segera ditangkap. Saddam mengirim pesan yang disiarkan oleh televisi $A l$ Arabiya dan menyatakan bahwa perang belum berakhir. Suaranya itu seperti di gurun pasir. Nyawa Saddam hanya menunggu waktu. Dia melindungi dirinya dengan melakukan penyamaran, memanfaatkan orang-orang yang mirip dengan dirinya, dan bahkan hidup secara nomaden.

Pada tanggal 13 Desember 2003, Saddam ditangkap di sebuah bungker di Kota Tikrit, daerah kelahirannya. Dia di penjara di sebuah penjara militer Amerika dekat Baghdad. Saddam dirawat oleh seorang perawat militer AS yang bernama Ellis. Ellis mengakui bahwa alasan politiklah yang melatar belakang Amerika Serikat menginvasi negaranya.

Pada tanggal 30 Desember 2006 pukul 06:10 waktu Irak dan bertepatan dengan hari raya Idul Adha, Saddam dieksekusi mati. Meski usia Saddam sudah uzur, tetapi banyak pihak yang sangat takut dan paranoid terhadapnya, khususnya Presiden AS George W. Bush dan sekutunya. Dia dijatuhi hukuman mati setelah dinyatakan bersalah atas kasus pembunuhan 148 warga Dujail pada tahun 1982 oleh pengadilan Irak yang dibentuk oleh Amerika dan sekutunya. Hal ini merupakan suatu kejanggalan politik yang terjadi di Irak seperti yang dilontarkan Saddam Hussein saat pengadilannya berlangsung. Mereka yang paling berbahagia atas kematian Saddam Hussein adalah George W. Bush, Amerika, sekutunya serta kelompok Syiah dan Kurdi. Sebaliknya, kaum Sunni merasakan duka cita yang mendalam.

Bagi rakyat Palestina, Saddam merupakan pahlawan yang memperjuangkan kepentingan Palestina. Saddam tidak pernah lelah membela kepentingan negara tersebut. Dia mendukung gerakan perlawanan rakyat Palestina terhadap Israel. Saat Perang Teluk I pada tahun 1991, Saddam meluncurkan rudal ke Israel dan membantu dana bagi keluarga korban pelaku bom bunuh diri. 
Eksekusi mati Saddam berlangsung di dalam ruangan kecil, dia menghadap kepada seorang hakim yang membacakan putusan vonis secara lengkap. Semula dia menjalankan prosedur dengan tenang, akan tetapi ketenangannya kembali terusik dengan adanya kamera yang merekam eksekusi tersebut. Kemudian dia menunjukkan lagi pemberontakannya dengan meneriakkan "Allahu Akbar" dan slogan-slogan perlawanan lainnya: "Hidup rakyat Irak!" dan "Hidup rakyat Palestina!". Saddam Hussein sadar bahwa hidupnya sudah diambang kematian. Meski dalam hitungan detik, sosoknya masih menampakkan ketenangan, ketegaran, dan kekuatan. Sebelum tali eksekusi Saddam dipasang di lehernya, dia masih berteriak lantang "Allahu Akbar! Irak akan menang dan Palestina adalah bagian dari Arab." Saddam Hussein meninggal pada usia 69 tahun, delapan bulan, dua hari. Setelah 22 jam eksekusi, dia dimakamkan di desa kelahirannya, Awja, Tikrit, 31 Desember 2006 pukul 04:00 pagi waktu setempat. Sejak eksekusi sampai pemakamannya, demonstrasi dari penjuru dunia terus berlangsung, mengutuk eksekusi hukuman gantung terhadap Saddam.

Telah diketahui bahwa Irak merupakan negara yang memiliki kandungan minyak terbesar kedua setelah Arab Saudi dan kualitas minyaknya termasuk yang terbaik. Siapa pun yang dapat "menguasai" Irak akan mudah memperoleh hak untuk mengeksploitasi. Kini, Amerika Serikat dan sekutunya seperti Israel dan Inggris menguasai Irak. Sejumlah pejabat Irak semasa Saddam berkuasa, seperti Deputi PM Tareq Aziz secara langsung menuduh AS ingin menguasai sumur-sumur minyak Irak (Mahmud, 2007: 1-61).

b. Fenomena perjalanan hidup Hanzhala, kartun yang merepresentasikan seorang Nàjī al-'Alī

Fenomena yang kedua yaitu perjalanan hidup Hanzhala, kartun yang merepresentasikan seorang Nājī al-'Alī saat berusia sepuluh tahun yang sudah menanamkan jiwa nasionalisme dalam dirinya. Anak asal Palestina yang memiliki cita-cita mulia untuk membebaskan negaranya dari penjajahan dan menyatakan merdeka. Dia juga merupakan sahabat karib Mathar. Al-'Alī dan Mathar hidup di tempat pengasingan yang sama yaitu, London.

Hanzhala (حنظة) adalah karakter Nàjī al-'Alī yang paling terkenal. Dia digambarkan sebagai anak laki-laki berusia sepuluh tahun yang muncul untuk pertama kalinya di Al-Siyasa, Kuwait pada tahun 1969. Kartun yang dibuat menceritakan pengalamannya sebagai pengungsi Palestina sejak masa kanakkanak dan jelas mencerminkan sikap politik, yang seringkali kritis terhadap rezim Arab. Posisi kartun tersebut berdiri sendirian membelakangi setiap orang yang melihatnya atau penonton dari tahun 1973. Walaupun seperti itu, dia tetap memberikan tanda dan peristiwa yang terjadi melalui gerak-gerik tubuh dan kejadian yang dilihat secara langsung.

Kedua fenomena tersebut di atas, menurut peneliti merupakan latar belakang bagi Mathar dalam penciptaan karyanya. Di waktu yang bersamaan pula, pada angka yang merujuk pada tahun 1999, yang menjadi judul syair Mathar terjadi penyerangan secara sistematis dan berkesinambungan yang diluncurkan oleh Amerika Serikat dan Inggris dengan melakukan serangan udara "Operation Desert Fox" atas Irak, negara kelahiran Mathar (Mahmud, 2007: 75). Selain itu, tahun 1999 adalah tahun berdirinya ISIS (Islamic State in Iraq and Syria, yang saat ini dipimpin oleh Abu Bakr Al-Baghdadi) yang awalnya didirikan dengan nama Jama'at al-Tauhid wal-Jihad (1999-2004) oleh seorang radikal Yordania, Abu Musab al-Zarqawi. Diketahui bahwa organisasi ISIS dikenal brutal karena mereka adalah kaum militan yang menginterpretasi Islam Sunni secara ekstrem. Mereka mengklaim bahwa dasar tindakan brutal adalah ayat Al Quran. Diberitakan pula di tahun tersebut seorang penyair Arab modern, 'Abdul-Wahhab AlBayati meninggal dunia. Syair-syair beliau banyak bertemakan nasionalisme, cinta, dan persahabatan ke dalam puisinya 
(seperti syair ciptaan Mathar) (Bustam, 2015:127). Semakin kuatnya berbagai macam gejolak permasalahan yang terjadi di negara kelahirannya memungkinkan bahwa seorang Mathar mengalami tekanan emosional sehingga dia membuat karya sastra dalam bentuk tulisan yang dalam hal ini adalah syair.

\section{Kesimpulan}

Berdasarkan hasil pembahasan dan analisis struktur teks syair 1999 karya Achmad Mathar, dapat disimpulkan bahwa interpretasi kondisi sosial penyair dapat ditelusuri dengan kajian struktur teks dengan menggunakan teori strata norma Roman Ingarden yang memiliki lima lapis yakni lapis bunyi, lapis arti, lapis hal-hal yang dikemukakan, lapis dunia, dan lapis metafisis. Untuk mempertajam interpretasinya, penelitian ini mengungkapkan kondisi sosial penyair berdasarkan pada teori solipsisme yang mengungkapkan dua fenomena yang berkaitan erat dengan terciptanya teks syair 1999. Fenomena pertama yaitu mengenai Saddam Hussein yang merupakan Presiden Irak. Dia pernah memiliki hubungan baik dengan dunia Barat kemudian menjadi musuh utama Barat pula. Ia juga memiliki cita-cita untuk kemerdekaan total masyarakat Timur Tengah dari hegemoni Barat yang direpresentasikan Amerika, Inggris dan Israel. Fenomena yang kedua yaitu perjalanan hidup Hanzhala, kartun yang merepresentasikan seorang Nàjī al-'Alī sahabat karib Mathar saat di London- saat ia berusia sepuluh tahun yang sudah menanamkan jiwa nasionalisme dalam dirinya. Anak asal Palestina yang memiliki cita-cita mulia untuk membebaskan negaranya dari penjajahan dan menyatakan merdeka.

\section{Daftar Pustaka}

Adonis. 2009. Arkeologi SejarahPemikiran Arab-Islam.
Diterjemahkan oleh Khairon
Nahdiyyin. Yogyakarta: LkiS.

Bagus, Lorens. 2000. Kamus Filsafat. Jakarta:Gramedia Pustaka Utama.
Bustam, Betty Mauli Rosa, dkk. 2015. Sejarah Sastra Arab Dari Beragam Perspektif. Yogyakarta: Deepublish.

Endraswara, Suwardi. 2012. Filsafat Sastra: Hakikat, Metodologi, dan Teori. Yogyakarta: Layar Kata.

Fathoni, Achmad Atho'illah. 2007. Leksikon Sastrawan Arab Modern: Biografi dan Karyanya. Yogyakarta: Datamedia.

Hasanuddin. 2009. Ensiklopedi kebahasaan Indonesia. Bandung: Angkasa Bandung.

Mahmud, NS. 2007. Detik-Detik Kematian Saddam Hussein. Yogyakarta: An Naba'.

Manshur, Fadlil Munawwar. 2007. SejarahPerkembangan

Kesusastraan Arab Klasik dan Modern. Bandung.

Mathar, Achmad. 2012. Al-A'mālul Kāmilah li Achmad Mathar. Mesir: Dārul Khulūd.

Mustakim, dkk. 2016. Pedoman Umum Ejaan Bahasa Indonesia. Semarang: Balai Bahasa Jawa Tengah.

Muzakki, Ahmad. 2006. Pengantar Teori Sastra Arab. Malang: UIN-Maliki Press.

Pamungkas, Imam. 2014. Gampang dan Praktis Berbicara Bahasa Arab Secara Otodidak. Jakarta Timur: Pustaka Makmur.

Pradopo, Rachmat Djoko. 2012. Pengkajian Puisi.Yogyakarta: Gadjah Mada University Press.

Ratna, Nyoman Kutha. 2004. Teori, Metode, dan Teknik Penelitian Sastra. Yogyakarta: Pustaka Pelajar.

Rusdianto, 2015. Bahasa Arab Tamlihi. Yogyakarta: Saufa.

Sangidu.2006.Pengantar Studi Linguistik Arab. Yogyakarta: Seksi Penerbitan Sastra Asia Barat Fakultas Ilmu Budaya UGM.

Tim Penyusun. 2016. Kamus Besar Bahasa Indonesia Pusat Bahasa: Edisi Keempat. Jakarta: PT Gramedia Pustaka Utama. 
Zaidan, Abdul Rozak, dkk. 1994. Kamus Istilah Sastra. Jakarta: Balai Pustaka.

Internet.https://en.wikipedia.org/wiki/Ah med_Matar (diakses pada 23
Maret 2018 pukul 20:23 wib).

.2017.http://www.alnakedaliraqi.n et/article/42946.php (diakses pada27Desember 2018 pukul 19:27 wib). 